\title{
Social media and the new struggles of young people against marginalisation: a challenge to missional ecclesiology in Southern Africa ${ }^{1}$
}

\author{
Nel, Reggie \\ University of South Africa \\ rwnel@unisa.ac.za
}

\begin{abstract}
Social media technologies have become a prominent feature of public life, but also the personal lives of young people. The question is whether the academic discourses on the missional church in southern Africa have taken this trend into consideration adequately. This article addresses this question by introducing a postcolonial missiological perspective on social media and the new struggles of young people against marginalisation. Through a literature review, the article appropriates research from sociologists, in particular Manuel Castells, firstly to show how subjects are constructed in this new, networked world order and secondly to show how social transformation is framed and engendered. It is concluded that these findings are the basis for the notion of the missional church as a social network. It is recommended that a subtheme, which prioritises the role of social media in this age of the network society, be established in the academic discourse on the southern African missional church in order to continue the dialogue with young people in their contemporary struggles.
\end{abstract}

\section{Keywords}

Social media, network society, missional ecclesiology, young people, and marginalisation.

\section{Introduction}

When a 15-year-old teenager was recently discovered in South Africa, on her way to join the Islamic State (ISIS) militant group, social media was pointed out as the way she was supposedly recruited. Indeed, Steinmetz (2014) makes

1 This article was first presented at the II International Congress of the Faculdades EST, under the theme "Religion, Media and Culture", on 8-12 September 2014 in Sao Leopoldo, Brazil. The financial support from Unisa, College of Human Sciences is acknowledged with gratitude. 
the following point: "Most teens live, at least in part, on social media, the virtual platforms that shape their real worlds - places where they joke, flirt and seek constant, elusive validation from their peers." This was therefore also their reality, as cohorts of this generation of young people, were participating in struggles against marginalisation and oppression all over the world, but in particular northern Africa in what became known popularly as the Arab Spring, and most recently amongst South African student movements, under the hashtag ${ }^{2}$ banner, \#RhodesMustFall and \#FeesMustFall. Ingram (2011) explains however, "In the end, it's not about Twitter ${ }^{3}$ or Facebook ${ }^{4}$ : it's about the power of real-time networked communication."

In this article I focus on the role of social media in these expressions of the new struggles of young people against marginalisation, but more specifically, its relationship to social networks and how it challenges southern African missional ecclesiology. It seems to me that the significance of social media in the new struggles of marginalised groups is not yet taken into account by southern African proponents of the missional ecclesiological discourse in their dialogue with younger generations, in specifically understanding the new terrain of social transformation (unlike groups like ISIS!) ${ }^{5}$. Social networks are here narrowly understood to be web services which facilitate its users to maintain a public or semi-public profile within a "bounded system" and through which they can articulate to a list of other users (often called 'friends') with whom they share a connection (Murthy 2012:1061; boyd $^{6}$ and Ellison 2008:211). While the immediate focus is on social

2 The term, hashtag, or commonly recognised on social media by the \# symbol, is defined as a symbol which is used to mark keywords or topics in a tweet. It was created organically by Twitter users as a way to categorize messages, (See https://support.twitter. com/articles/49309\#) but it gradually became powerful rallying calls, slogans and banners as these social media sites became used in campaigns.

3 Twitter is a social media website (www.twitter.com) or application, where users send messages, restricted to 140 characters in length, termed 'tweets' to their list of 'followers' or the public. While there are many other social media websites, Ingram's point is to highlight the most popular sites used in the named social upheavals.

4 Facebook is another well-known and popular website (www.facebook.com), where users can 'post' status messages, photos, and their locations, which allow for their 'friends' to 'comment', 'like' or 'share'.

5 In this respect, one can, however, refers to the valuable work of Cloete $(2012,2015)$ from a practical theological perspective on youth and digital culture and the media. Yet this valuable work is not yet directly related to youth activism and missional ecclesiology, which is the focus of this article.

6 danah boyd, is a social media, popular culture and youth researcher, who consistently spells her name and surname in lower case throughout all her writing. In this article, I 
media in the struggles of young people, and its relationship to the network society, I relate this focus here, broadly to my overall aim of discerning a southern African Reformed missional ecclesiology by nurturing a dialogue with these young people in order to understand how such new struggles challenge, or better remix, the existing theology of the missional church.

In addressing this concern in this article, I first explain my particular perspective on the relationship between social media and the new youth struggles as they happened in northern Africa; then I refer to the recent work of sociologists on these development, in particular Manuel Castells, as he analyses the new expressions of struggle and how it plays out within his older notion of a network society $(1997 ; 2011)$, a context of interconnectedness. I relate this notion to his theory of social transformation in the network society. The article concludes with some brief challenges to southern African missional ecclesiology, in relation to these struggles.

\section{A postcolonial, missiological methodology}

While the article is based on a critical literature review, this is a postcolonial missiological study. A critical literature review was conducted according to what Mouton calls, a non-empirical "literature review" (Mouton 2001:179). There is therefore no separate literature review section because the findings from the critical review of the literature forms the basis for the whole argument and the flow of the article. In literature studies like this, therefore, the researcher focuses on analysing the key literature on the specific topic and Mouton (2001:179-180) describes and defines them as:

studies that provide an overview of scholarship in a certain discipline through an analysis of trends and debates [...] A review of the literature is essentially an exercise in inductive reasoning, where you work from a "sample" of texts that you read in order to come to a proper understanding of a specific domain of scholarship.

I integrated these analyses of "trends and debates" from sociological studies, as Mouton indicates, in order to come to a "proper understanding" in order to discern, missiologically, a postcolonial southern African missional ecclesiology in dialogue with young people and students active in social 
movements. It would seem to me that while there is a welcome proliferation of work on the missional church from South Africa (Hendriks 2004:2125, 2008; Dames 2007:34-53; Kok and Niemandt 2009; Saayman 2010:5-16; Niemandt 2010:397-413, 2012; Sheridan 2012) and of African ecclesiology (Solomon 2001; Maluleke 2008; Orobator 1999; Saayman 2009:287-300; Mwambazambi 2011) the theory on social transformation in the current age, through a social movement lens and therefore also the role of social media, has not yet been researched and related to these conversations. I therefore did this research through a specific missiological methodology, namely what I call, a postcolonial missiological matrix for understanding youth movements (Nel 2013:140-198; 2014). Through this methodology, I maintain the creative interplay between questions about insertion, social analysis, theological reflection and action plans (Holland and Henriot 1983; Karecki 2002:138-141, 2005:159-173; Kritzinger 2002:144-173, 2007:764790). I also take into account insights from new social movement studies (Ray and Anderson 2000; Tarrow 1998; Larana, Johnston and Gusfield 1994; Leffel 2007:15-44; 177-211), with an emphasis on agency, participant biography, the opportunity structures and rhetorical framing of their world, through their interpretation and mobilisation of their authoritative sources which, in turn, shapes their movement culture.

In using the word 'understanding' and not 'analysis', I concur with the postcolonial activist-theorist of Black Consciousness Steve Biko's emphasis on understanding in scholarship. Biko, in the context of his time, argues that one study what he calls, "the black world [...] not from a detached point of view but from the point of view of a black man, conscious of the urgent need for an understanding ...” (Biko 1978:29). This emphasis correlates with the distinction made by the Chilean economist Max-Neef (1994:120122) much later between a 'clinical knowledge' of knowing detail on the one hand, and then 'understanding', on the other hand. Max-Neef (1994:120) explains this distinction when he defines analysis or clinical knowledge as describing and explaining a phenomenon from a distance. Understanding however, relates, for him, to a more intimate relationship ${ }^{7}$ leading to experiencing and gaining a deep sense of what he would call enlightenment

7 Max-Neef illustrates this distinction by using the example of doing research and getting all the facts about love. For him, it is only in experiencing love that one may start to gain a deeper level of understanding. Max-Neef (1994: 121) states that "we can only attempt to understand that of which we become a 'part' and what we 'feel"'. 
and wisdom. While Max-Neef's perspective is limited as an economist, a postcolonial missiological perspective starts from a commitment to God's mission, as suggested by liberation theologians, from the location of those on the "under-side" or "standing with..." marginalised groups in empathy and solidarity with their praxis. This commitment resonates with what Bosch (1991:425) calls an "intersubjective" epistemology and is relevant in the search for a sensitive and creative dialogue with the contemporary cohort of younger generations, or "catching up" ${ }^{8}$ with the impulses of the new era of youth struggles.

This shift towards an intersubjective epistemology is rooted in the Trinitarian theology of God's mission. While God's artistic creativity is poured out and performed in all of creation, and Jesus' incarnation affirmed this world as the arena of God's loving outpouring of Himself; this shift also affirms the continuing presence and energy of the Holy Spirit, opening us to an always deeper revelation of God's impulses. Kritzinger (2002:144-173) argues correctly that these notions of "understanding" form the epistemological heart of a missiological methodology, as articulated amongst others, by the apostle Paul. He shows how Paul in 1 Cor. 2:6-16, illustrates the Spirit's work as in "searching" and "questioning" everything, but also, and intimately connected to these, searching the "depths of God" (v10). Here, Paul's pneumatology articulates a deeper and more intimate knowing, in relation to the presence of the Holy Spirit within the world, or what one can also call "spiritual growth". This spiritual growth is however more than a pious individualism on the one hand, or activist dualism on the other hand. It is also more than a modern, objectified and clinical (social) "analysis" of the context, or social actors, in the quest for objective truth.

Hence, in this methodology, or what I prefer to call the interactive matrix between the different dimensions of participant biography or agency, opportunity structures and the rhetorical framing of their world, and through the young people's interpretation and mobilisation of their authoritative sources which shapes their movement culture, we hope gain a missiological understanding of the relation of social media with the (new) struggles of young people.

8 See also practical theologian Ganzevoort (2009:5-6) who speaks of practical theology as "tracing the sacred". 


\section{Social media and its relationship with the (new) struggles of young people}

Social media has redefined youth activism in a specific way. In the next section I aim at presenting the findings, in terms of the questions around participant biography or agency; opportunity structures and the rhetorical framing of their world, while the dimensions of their interpretation and mobilisation of their authoritative sources, which shapes their movement culture, will be integrated into the discussions. I will start with the question about agency.

\subsection{Agency - writing their identity and creating profiles}

In the literature on social media and its relationship to social networks, it is argued that social media or what is sometimes called social media technology is a "medium wherein 'ordinary' people in social networks (as opposed to professional journalists) can create user-generated 'news' (in a broadly defined sense)" (Murthy 2012:1061; Bhuiyan 2011:14; Lotan et al. 2011:1375-1405). With social media, then, the interaction, sharing, engagement and produced is most often with other people or institutions the users have found of interest, leading to interactions with what is called their 'followers', often strangers. Murthy (2012:1062-1063) shows that this medium aims to facilitate social interaction and collaboration and in this sense it is part of the larger trend of interactivity.

With social networks, however, users interact with individuals that they mostly know offline (boyd 2007:119-142; boyd and Ellison 2008: 210-230). For boyd (2007:124), social networking sites are based around the ritual of creating a "profile", i.e., a form of individual (or less frequently, group) home page, which offers a description of each member. The profile creates, writes out and shares an identity in a particular connected or networked community. Ingram's point in relation to the struggles of young people in northern Africa in particular, is relevant. He shows that the social media technologies were appropriated specifically to connect, inform and organise social movements, driven mostly by young people and students. Honwana (2013:2) also introduces her study of these youth movements, by stating the following about the uprising in Tunisia: 
They marched alongside other protesters, challenging the police, and skilfully used the internet to publicise, in real time, the confrontations between youth and the police, exposing the political repression and brutality of the Ben Ali regime. Their actions, along with those of local internet users, helped to transform an initially localized uprising into national and international news. In a matter of seconds, Tweets, Facebook messages and YouTube videos with images of young protesters being violently attacked by the police reached millions of viewers across the country and abroad ... the government had no effective means of attacking the insurgency's virtual networks.

In attempting to understand these youth movements, social commentators argue that these networked (social) movements were in essence signals of a new "global political awakening" around the issues of increased social insecurity, growing economic inequalities, and a deep discontentment with unresponsive post-colonial governments and multi-lateral institutions (Honwana 2013; Castells 2012; Rieger \& Pui-lan 2012; Mason 2011; Marshall 2011). However, the profiles created, meaning the agency or subjectivity of the protesters, remained critical in the midst of these networks an expression of resistance. Castells's (2012:11) framework of the role of identity and subjectivity in the network society is critical to understand this. He posits that

the constitution of subjects, at the heart of the process of social change, takes a different route to the one we knew during modernity, and late-modernity: namely, subjects, if and when constructed, are not built any longer on the basis of civil societies that are in the process of disintegration, but as prolongation of communal resistance. While in modernity (early or late) project identity was constituted from civil society (as in the case of socialism on the basis of the labour movement), in the network society, project identity, if it develops at all, grows from communal resistance.

Castells explains that identity ${ }^{9}$ as a source of people's meaning and experience, and at the root of building subjects, is socially constructed. The

9 He distinguishes three forms and origins of identity building (2011:11), namely, "legitimizing identity", introduced by dominant institutions to extend and rationalise their domination; "resistance identities", generated by those who are in a position 
role of technology, like social media then, or what Castells calls "mass selfcommunication" (2011), is as a tool and medium to build this autonomy and confront the new configurations of power on their own terms, i.e., the networking power of the powerful institutions in the network society. Yet, these mass self-communication or new media technologies are more than mere tools; they also constitute the new movements. In this, Castells suggests that without these new media technologies, the new social movements would not have been conceived (2012:15). In this, it seems further that it is pertinently younger generations who are on the forefront of street battles with security forces but, more and more, also the battles on the internet. One cannot understand new youth and youth movements apart from these networked realities and Castells defines these movements as "purposive collective actions whose outcome, in victory as in defeat, transforms the values and institutions of society" (1997:3). The question now arises how this new construction of subjects, is relevant to the southern African realities?

In South Africa, more pertinently, the struggles of young people and students have shifted from activism against colonial racism ${ }^{10}$, towards activism against marginalization in a post-colonial, neo-liberal context ( Nel 2014). Previously, I argued that the notion of "youth marginalisation" was socially constructed within a broader framework of vilifying (black) youth agency in the 1990s in South African media and it has become a key theme in youth research since the 1990s (Swart 2013:5-9). In my work, I would frame this new activism against marginalization, as a growing discontent in a specific post-colonial context, but more importantly, as a sign of agency amongst youth and student movements. The most recent proliferation of student activism around the issues of transformation at universities, organised around symbols on campuses is a case in point. This agency (as manifested in activist profiles) was however produced in and through a particular opportunity structure or rhetorical framing of their world.

devalued or stigmatized by the logic of dominance and then, for him, "project identities", where the social actors, "on the basis of whichever cultural materials", construct a new project identity, which redefines their position and pushes for the "transformation of the social structure".

10 It needs to be qualified that recently university students from various so-called "liberal" universities in South Africa again started to engage the challenge of transformation, through the \#RhodesMustFall campaign, which aims at the removal of statues which they identify to be colonialist symbols and also the changing of names of public spaces which refer to these figures. 


\subsection{Opportunity structure and rhetorical framing of their world}

Social movements, like the youth movements in northern Africa, have a particular understanding of and rhetorical techniques for constructing their world. As Leffel (2007:180) explains:

Considerable work [...] occurs within movements as activists try to understand their circumstances and seek avenues of action. This rhetorical activity - the construction of an ideological architecture to unite observations, analyses, and interpretations with actions - creates a framework that names grievances, makes claims, legitimates action, and calls others to join in social action. All of this work is included in initiating and forming movements.

The current upsurges in youth responding to their social situation in the virtual networks of the internet, as well as in public spaces, are framed rhetorically to be within and responding to the pervasive reality of what is often termed, neo-liberal globalisation - specifically in the ways it relates to the upsurge in connectivity and high tech networking (Mason 2011:6585; Rieger \& Pui-lan 2012:Loc.94,119). While new social movements in Africa cannot be properly understood without taking into account the history of the development of successive waves of slavery and colonialism, one also needs to take into account the post-colonial reality of neo-liberal globalisation, in terms of what sociologist, Manuel Castells has started to call "informationalisation" or the "information technology revolution and the restructuring of capitalism" (Castells 1997:1). Castells argues that we are living in a different world from the one of the industrial age, and that the (older) world also formed particular social movements. He states that "[o]ur world and our lives, are being shaped by the conflicting trends of globalisation and identity" (1997:1) and therefore these new social movements can only be understood in terms of their responses to globalisation and "informationalisation" (1997:68), what he calls the "network society".

In his analysis of the Arab Spring, Noam Chomsky (2011), an authoritative thinker about these movements, links these upheavals directly to what he calls, the "New World Order". Chomsky then points to the important role that the military, and in the Unites States of America in particular the Pentagon, played in creating this new world. He shows that the Pentagon financed what became "the next phase of the high-tech economy at that time: computers, micro-electronics, shortly after, the internet” (Chomsky 
2011). Through public military spending the public was paying the costs and absorbing the risks of this research in the quest for new military technology, while the eventual profits were privatized - "in the case of computers and the internet, after decades.” (Chomsky 2011). Castells (2011) concurs with this perspective. After showing the direct link between state spending and military interests in Western Europe, Castells (2011:Loc. 2561) states, "Even in the US it is a well-known fact that military contracts and Defence Department technological initiatives played decisive roles in the formative stage of the information technology revolution; that is between the 1940s and the 1970s." He concludes, "Thus, the state, not the innovative entrepreneur in his garage, both in America and throughout the world, was the initiator of the information technology revolution" (2011:Loc. 2587).

The consequence of these investments, Castells shows, was the shift towards the network society, expressed through this "New World Order" (2011). It has been created and maintained by the multi-billion dollar technology industry, but also the arms industry and these origins are significant since they shaped the current context within which youth have to renegotiate meaning. Jeffrey and McDowell (2004:131) state:

The sheer speed of neoliberal economic and social reform in many parts of the globe has effected profound changes in young people's experiences. Nations are implicated in a changing global order in which government disinvestment in welfare measures, transnational economic competition, high rates of unemployment, and economic recession is increasing pressures on parents and young people.

While it was the younger activists and students who experienced the dire consequences of this new networked reality, they also appropriated these technological advances in their struggles against this marginalisation. One therefore witnesses an upsurge in protest, (of different kinds) with incidents of violent clashes between authorities against mostly youth and student movements in the USA itself, and in various other Western European countries, in the struggles for human rights and ecological justice at global meetings of the G8 leaders and World Economic Forum, and also in South African student movements. With these new youth movements, as in the northern African countries, we can see different kinds of movements, which are also organised through social media networks, using social 
media sites. The upsurge in what became popularly known as the "Occupy Wall Street" movement, or \#OccupyWallStreet, started from the USA, in the aftermath of what Terreblanche (2009b:3) calls "The Second Meltdown of the Ideology of Market Fundamentalism.” In these movements, young people and students, in the midst of their own personal debt crisis and of government interventions to "rescue" multi-national corporations and investment banks in this meltdown, started to identify themselves on social media platforms, as being part of the $99 \%$ of the population who, they argue, are not directly responsible for these economic woes (Rieger \& Pui-lan 2012:Loc.103; Mason 2011:84; Castells 2012). Their activities are mostly organised through social media platforms, like Twitter, but also by hackers who have attacked government websites. These activists position themselves against what they call the $1 \%$ of the super-wealthy, who seem to be buffered from the impact of the economic meltdown through the named government interventions. What is significant is the impact of these activists, on a local level through physical occupations of government sites and their subsequent arrests, but also, in the global scope of these new social movements through their social media and hacking campaigns. Castells (2011:1) explains the background of this shift in terms of the notion of counter power in the network society:

[W] herever is domination, there is resistance to domination, be it political, cultural, economic, psychological, or otherwise. In recent years, in parallel with the growing crisis of political legitimacy, we have witnessed in most of the world the growth of social movements, coming in very different forms and with sharply contrasted systems of values and beliefs, yet opposed to what they often define as global capitalism.

For him, this counter power takes on different forms in terms of their political and cultural realities in this phase of "techno-economic globalisation" (Castells 1997:3), or the network society. He explains:

At the same time, because power relations are structured nowadays in a global network and played out in the realm of socialized communication, social movements also act on this global network structure and enter the battle over the minds by intervening in the global communication process. They think local, rooted in their society, and act global, confronting the power where the 
power holders are, in the global networks of power and in the communication sphere (Castells 2011:1).

The new site of social transformation, for Castells then, is not merely the official (outdated) nationalist political parties or even civil society (1997:8$9,11,360 f$.), but it is global, being fought on the terrain of information and communications technologies, that purport to take precedence over human life and the preservation and integrity of the environment. Castells (1997:360-361) concludes as follows:

[S]ocial movements emerging from communal resistance to globalisation, capitalist restructuring, organisational networking, uncontrolled informationalism, and patriarchalism - that is, for the time being, ecologists, feminists, religious fundamentalists, nationalists, and localists - are the potential subjects of the Information Age.

In these movements he identifies the key actors to be the "prophets" and, as the main agency, new social movements, "a networking, decentred form of organisation and intervention [...] mirroring, and counteracting, the networking logic of domination ..." (Castells 1997:362).

These insights about a new theory of social change and specific social actors in the network society have implications for faith communities and their dialogue with young people, but more importantly, as we grapple with the bigger question of what the implications are for the southern African missional ecclesiological discourse, which takes this agency of younger people seriously.

\section{The missional church as social network?}

In the opening sections of this article I alluded to the growing salience of social media applications amongst fundamentalist militant movements, like ISIS in the Middle East, but also, in the struggles of young people against marginalisation. That was perhaps a bit sensationalist. Yet, from the findings presented in this article, one can state that the construction of localised identifications through social media, as shown in the previous section, has become the space and basis for resistance and social transformation. Youth (social) movements affirm growing and sprawling networks of different identifications around resistance and inspiring ideas. This means that for missional faith communities, the socio-ecclesial identifications 
and realities emerging from different social media platforms are reshaping younger members in faith communities as they continue to mix new modes of understanding themselves and their world. These new modes used by young people to understand and construct themselves, go beyond the older imaginations, or what Castells (1997:8; 2011:11) would call "legitimising identities". In terms of the southern African context, the Belhar Confession speaks of this reality of diversity as "opportunities for service and enrichment" (Belhar Confession 1986). The question then is what would be the implications for a southern African missional ecclesiology.

The South African missional ecclesiological discourse, as indicated earlier in this article, is dominated mostly, by scholars from the Dutch Reformed tradition. This is our historical legacy and tradition. The Reformed tradition in the Netherlands faces its own unique challenges, which cannot be ignored, as its South African counterparts seek to embody an African Reformed missional ecclesiology. Zondervan (2006:51-66), in his observations from Dutch society, also wrestles with the networked reality and the influence of social media. He speaks of a "transformation of religion" (Zondervan 2006:52), which leads to new forms, including the forms of the institutional church. He further confirms the impulses from the aforementioned findings that traditional unitary structures, as the "pillars" for social stability, but also of religious experience and faith formation, are losing their grip in favour of loose networks (movements) where the character of association is changing (Zondervan 2006:58). Younger generations, Zondervan argues, are still interested in religious experience, but this interest "surges up in new forms, at new places and is connected to their social associations in new ways" (Zondervan 2006:55). He prefers the notion of "networks of belonging" (Zondervan 2006:57) and is not in favour of revitalising the existing institutional, hierarchical church. Young adults, in his (western European) context, are not looking for hierarchical institutions, they search rather for "flexible forms of association that offer them place and occasion to deal with their longing for religious knowledge and experience" (Zondervan 2006:58). He then finds hope in what he calls "temples of loose connection and spiritual practice" (Zondervan 2006:60). The old model of church as a membership based "club", with strict adherence to one programme, directed by the clergy, is out-dated. He argues in favour of spaces, characterised by loosely connected participants, where moral and spiritual potential are explored. 
The impact of these explorations is exchanged amongst these participants, often through social media networks, sharing photos and stories, even though it is often happening incidentally.

Zondervan (2006:60-61) therefore suggests that the (organic) metaphor of the church as the body of Christ, which articulated the unity as well as the diversity of gifts and functions, has remained within the realm of being a membership-based model, "wedded to institutional and cultural forms of local church and congregational life inherited from the $19^{\text {th }}$ and $20^{\text {th }}$ centuries". Instead, he argues for the image of the church as temple (of the Holy Spirit). He engages Ward's (2008) proposal for a "liquid church" and challenges Ward's way of correlating theological ideas with sociological data. Ward (seemingly) still wants to revitalise existing and, for him, outdated, church forms. However, because of the Dutch context, where most young adults do not have any experience of "church", he wants to start from the existing lived religious experiences 'outside' the traditional ecclesiastical institutions.

Unlike Zondervan's context, from the southern African perspective, it seems that young people are still aware of institutional ecclesiastical institutions at least. In their new struggles against marginalisation, they are however not stuck in this institutional memory and forms; they are mostly either challenging it, or leaving these forms behind. In the network society the remaking of the church, takes this historical journey seriously. This is also in line with a postcolonial understanding of history - one cannot simply "jump over" the shadow of history of Christendom, as suggested by Zondervan. In taking his proposals seriously, I would therefore argue for the idea of remixing existing institutions, in terms of the notion of social network. In my view, the existing events and connections within local congregations allow for the possibility that such congregations may be the nodes of a broader network.

Within the Reformed tradition, in terms of the marks of the true church, one would see the preaching of the Word, or the ministering of the sacraments, as connection points within a broader network, while the application of discipline, the third mark, centres on maintaining the bonds between these connection points. This networking logic and imagination also affirms in a non-hierarchical mode, the idea of physical gatherings and meetings as connections. Congregations gathering for discernment, for joint service 
and celebration, are not associated in terms of corporate models any longer, with a top-down imagination, mirroring colonial institutions. This new imagination subverts this continuation of ecclesial hierarchy and allows for the whole covenant community, meaning, children, young people, women, or any other marginalised groups, like people with disabilities or who are otherwise marginalised in society, to share in and connect with the life of the faith community. This might happen for some occasionally (through loose connections), for others on a more regular basis, but finally the community forms a social network which connects all these different identifications and situations.

\section{Conclusion}

In this article, I started with the dark side of the power of social media technologies, namely that it is becoming a prominent feature of militant groups in their public appearances and actions, but also, in the personal lives of young people. Academic discourses in all disciplines of theology, also on the missional church in southern Africa, have to take this development into consideration. I subsequently aimed to introduce this concern, by searching for a postcolonial missiological perspective on social media in the context of the network society and the new struggles of young people against marginalisation. This perspective aims at understanding the use of social media by these young people as a basis for dialogue, in the quest for discerning the mission of God in the world.

While this study was limited to the recent waves of upheavals in northern Africa, through a focussed literature review it became clear, in particular through the work of Manuel Castells, that subjects are constructed in a different manner than before in this new, networked world order as agents of change. The creation of social media profiles, of an identity with a community of "friends" or "followers", it was shown, is more than a pass-time in a virtual space; for the new social movements of younger people also aim to resist the new power constellations of globalisation and informationalisation. Social transformation is thus engendered and framed in a different way through specific rhetorical techniques, which trace the prominence of the networking logic to specific economic and military goals. However, while the social media do not create the revolutions, young people also utilise these technologies to inform, connect and mobilise new social movements. 
These findings are then the basis for remixing the notion of missional church as a social network. The challenges raised in this article are pointers in a new direction, but they also suggest an agenda to a bigger research project. It is therefore recommended that the role of social media in this age of the network society be considered as a key priority in further academic research on the southern African missional church, in order to continue to nurture a sensitive and respectful dialogue with young people in their contemporary struggles.

When a 15-year-old teenager was discovered on a flight in South Africa on her way to join a militant group, the social media were pointed out as the way she was supposedly recruited. However, the deeper reality was that young people such as this girl want to be recognised as agents for hope and transformation. Social media are not the problem. The question is whether we, as faith communities, are willing to be challenged by these young people as they pursue their own conceptualisations of a new world. The notion of the church as a social network is therefore not rooted and maintained simplistically in technological advances; it is rooted in being connected to God through the searching and connecting, but also empowering presence and work of the Holy Spirit. It is in these real-time (connected) spaces where social media may serve God's mission so that 15 -year-olds can discover a new subjectivity, as agents of hope - but also be discovered, as showing the way for the church.

\section{Bibliography}

Belhar Confession 1986. Bellville: LUS Drukkery.

Biko, SB 1978. I write what I like. Johannesburg: Picador Africa.

Bosch, DJ 1991. Transforming Mission: Paradigm shifts in Theology of Mission. Maryknoll New York: Orbis.

Bhuiyan, SI 2011, Social Media and Its Effectiveness in the Political Reform Movement in Egypt. Middle East Media Educator, 1(1):14-20.

boyd, dm 2007. Why Youth (Heart) Social Network Sites: The Role of Networked Publics in Teenage Social Life. In MacArthur Foundation Series on Digital Learning - Youth, Identity, and Digital Media Volume (ed. David Buckingham). Cambridge, MA: MIT Press. 
boyd, dm \& Ellison, NB 2008. Social Network Sites: Definition, History, and Scholarship. Journal of Computer-Mediated Communication, 13:210-230.

Castells, M 1997. The Power of Identity. Massachusetts: Blackwell.

Castells, M, Fernanez-Ardevol M, Qiu JL and Sey A 2007. Mobile Communication and Society (Information Revolution and Global Politics). Cambridge: MIT Press (Kindle Edition).

Castells, M 2011. The Network Society. Massachusetts: Blackwell (Kindle Edition).

Castells, M 2012. Networks of Outrage and Hope: Social movements in the internet age. Cambridge: Polity Press (Kindle Edition).

Chomsky, N 2011. [Online] http://www.alternet.org/story/149786/chomsky:_why_ the_mideast_turmoil_is_a_direct_threat_to_the_american_empire/?page=entire [Accessed: 02 August 2014]

Cloete, AL 2012. Youth culture, media and sexuality: What could faith communities contribute? HTS Teologiese Studies/ Theological Studies 68(2), Art. \#1118, 6 pages. http:// dx.doi.org/10.4102/hts. v68i2.1118

Cloete, AL 2015. Living in a digital culture: The need for theological reflection. HTS Teologiese Studies/ Theological Studies 71(2), Art. \#2073, 7 pages. http://dx.doi.org/10.4102/ hts.v71i2.2073

Dames, GE 2007. New frontiers for mission in a post-modern are:

Creating missional communities. Missionalia 35(1): 34-53.

Ganzevoort, R 2009. Forks in the Road when Tracing the Sacred: Practical Theology as Hermeneutics of the Lived Religion. Presidential address to the $9^{\text {th }}$ conference of International Academy of Practical Theology. [Online] http://www.ruardganzevoort.nl/pdf/2009_Presidential.pdf [Accessed: 01 August 2014]

Hendriks, HJ 2004. Studying congregations in Africa. Wellington: Lux Verbi. Holland, J and Henriot, P1983. Social analysis. Linking faith and justice. Maryknoll: Orbis.

Honwana, A 2013. Youth and revolution in Tunisia. London: Zed Books (Kindle Edition). 
Ingram, M 2011. It's not Twitter of Facebook, It's the Power of the

Network. Gigaom. [Online] https://gigaom.com/2011/01/29/twitter-facebook-

egypt-tunisia/ [Accessed: 21 August 2014]

Jeffrey, C and McDowell, L, 2004. Youth in a comparative perspective:

Global Change, Local Lives. Youth \& Society, 36(2): 131-142. doi: $10.1177 / 0044118$ X04268375

Karecki, M (ed.) 2002. The making of an African person. Essays in honour of Willem Saayman. Pretoria: Daan Roux Printers.

Karecki, M 2005. Teaching Missiology in Context: Adaptations of the Pastoral Circle. In Wijsen, Henriot and Meija (eds.). 2005:159-173.

Kok, J \& Niemandt, CJP, 2009. (Re)discovering a missional-incarnational ethos, HTS Teologiese Studies/Theological Studies 65(1), Art. \#274, 7 pages. http://dx.doi. org/10.4102/hts.v65i1.274

Kritzinger, JNJ 2002. A question of mission - A mission of questions. In Karecki 2002:144-173.

Kritzinger, JNJ 2007. Nurturing Missional Integrity. Unpublished Paper.

Larana, E, Johnston, H and Gusfield, JR 1994. New Social Movements:

From Ideology to Identity. Philadelphia: Temple University Press

(Kindle Edition).

Leffel, G 2007. Faith seeking Action: Mission, Social Movements, and the Church in Motion. Lanham Toronto Plymouth: Scarecrow Press.

Lotan, G, Graeff, E, Ananny, Gaffney D, Pearce, I and Boyd, D 2011. The Revolutions Were Tweeted: Information Flows During the 2011 Tunisian and Egyptian Revolutions. International Journal of Communication, 5:1375-1405.

Mason, P 2011. Why it's still kicking off everywhere: The New Global Revolutions. London: Verso (Kindle Edition).

Max-Neef, M 1994. Looking at poverty from a Chilean perspective. In Koegelenberg (Ed.). 1994:120-131.

Maluleke, TS 2008. A postcolonial (South) African church: Problems and promises. Desmond Tutu Lecture, delivered at the University of the Western Cape. 
Mouton, J 2001. How to succeed in your Master's and Doctoral studies. Pretoria. Van Schaik

Murthy, D 2012. Towards a Sociological Understanding of Social Media: Theorizing Twitter. Sociology, 46:1059-1073. doi: $10.1177 / 0038038511422553$.

Mwambazambi, K 2011 A missiological refection on African ecclesiology. Verbum et. Ecclesia 32(1), Art. \#482, 8 pages. doi: 10.4102/ ve.v32i1.482. Nel, RW 2012. Mission as Solidarity - In the shadow of Empire. In Oden, Kjellin and Isaksson (Eds.). 2012:76-96.

Nel, RW 2013. Discerning an African Missional Ecclesiology in dialogue with two uniting youth movements. Unpublished DTh (Missiology) dissertation, Pretoria: University of South Africa.

Nel, RW 2014. Discerning the role of faith communities in responding to urban youth marginalization. HTS Teologiese Studies/Theological Studies 70(3), \#2743, 8 pages, doi:10.4102/hts.v70i3.2743.

Niemandt, CJP 2010. Five years of missional church: Reflections on missional ecclesiology. Missionalia 38(3):397-413.

Niemandt, CJP 2012, Trends in missional ecclesiology, HTS Teologiese Studies/Theological Studies 68(1), Art. \#1198, 9 pages. http://dx.doi. org/10.4102/ hts.v68i1.1198.

Orobator, OA1999. Missionary Ecclesiology: An Introduction. Nsukka: Fulladu Publishing Co.

Ray, PH \& Anderson, SR 2000, The cultural creatives: How 50 million people are changing the world, Three Rivers Press/Random House, New York.

Rieger, J and Pui-lan, K 2012. Occupy Religion: Theology of the Multitude. Lanham: Rowman \& Littlefield Publishers, Inc (Kindle Edition).

Saayman, W 2009. Missionary ecclesiology: A perspective from history. Studia Historiae Ecclesiasticae 35(2):287-300.

Saayman, W 2010. Missionary of missional: A study in terminology. Missionalia 38(1):5-16. 
Sheridan, TM 2012. Being a hermeneutic of the gospel: Hermeneutical and epistemological foundations for a missional ecclesiology. Unpublished DTh (Missiology)doctoral dissertation, Stellenbosch: University. http://scholar.sun.ac.za/ handle/10019.1/19913

Solomon, A 2001. The missiological dimensions of African ecclesiology. Unpublished DTh (Missiology) doctoral dissertation, Pretoria: University of South Africa.

Steinmetz, K 2014. Teen Girls describe the Harsh Unspoken Rules of Online Popularity. Time. [Online] http://time.com/3067694/weheartit-teengirls-bullying-instagram/ [Accessed: 21 August 2014]

Swart, I 2013. Youth at the margins: Introducing a new research initiative in an ongoing South-North collaboration in the context of international diaconia. Diakonia 4(1):2-26.

Tarrow, S 1998. Power in Movement: Social Movements and Contentious politics. Cambridge: Cambridge University Press (Kindle Edition).

Terreblanche, S 2009a. The Second Meltdown of the Ideology of Market Fundamentalism. Reformed World 59(1):03-18.

Terreblanche, S 2009b. The American Empire and the entrenchment of Global inequality. In Boesak and Hansen (Eds.). 2009:31-48.

Ward, P 2008. Participation and Mediation: A Practical Theology for the Liquid Church. London: SCM Press.

Wijsen, F 2005. The Practical-Theological Spiral: Bridging Theology in the West and the Rest of the World. In Wijsen, Henriot and Meijsa. 2005:129-147.

Wijsen, F, Henriot, P and Meijsa, R (Eds.). 2005. The pastoral circle revisited. A critical quest for truth and transformation. Nairobi: Pauline Publications.

Zondervan, T 2006. Faith in networks: Religious education of Dutch young adults in a 'post-ecclesial era'. Journal of Youth and Theology 5(1): 51-66. 